\title{
Complete genome of a novel virulent phage STO lysing Escherichia coli H8
}

Honghui Liu, Xinchun Liu* and Jinqing Li

\begin{abstract}
Phage STO lysing Escherichia coli H8 was isolated from wastewater and sequenced using an Illumina HiSeq system. Genomic analyses revealed that it was virulent phages and contained a circular double-stranded DNA genome, consisting of 170,496 nucleotides with an average $G+C$ content of $37.67 \%$. This study may provide possible alternative materials for phage therapy.
\end{abstract}

Keywords: Escherichia coli, Virulent phage, Complete genome, Phage therapy, Antimicrobial agents

\section{Introduction}

A large number of antibiotics were produced and widely used in medical and agricultural areas. These substances in the environment didn't tend to be biodegradable, and were easily stored and accumulated in water and soil environment and even in the atmospheric environment [1-3]. Recently, antibiotics had been recognized as the emerging environmental pollutants, because of their potential undesirable effects on the ecosystem and human health [4-6], such as antibiotic resistance. The resistance of bacteria to current antibiotics increased the difficulty in medical treatment, which accounted for 23,000 deaths annually in the USA. The spread of antibiotic resistant bacteria and antibiotic resistance genes in the environment was a major public health issue. Obviously, strict control of the use of antibiotics and the development of a possible alternative medicine seemed extremely urgent.

Compared with antibiotics, phage therapy had the advantages of high specificity, few side effects and capacity for low-dosage use and so on [7]. In particular, it was alternative and effective to adopt phage therapy to treat diseases caused by antibioticsresistant bacteria strains [8]. Currently phage therapy mainly had single phage treatment, multiple phage treatment and combined therapy of phage and antibiotics. More recently, bacteriophages had been

\footnotetext{
* Correspondence: xcliu@ucas.ac.cn

College of Resources and Environment, University of Chinese Academy of Sciences, Beijing 100049, China
}

(c) The Author(s). 2017 Open Access This article is distributed under the terms of the Creative Commons Attribution 4.0 International License (http://creativecommons.org/licenses/by/4.0/), which permits unrestricted use, distribution, and reproduction in any medium, provided you give appropriate credit to the original author(s) and the source, provide a link to the Creative Commons license, and indicate if changes were made. The Creative Commons Public Domain Dedication waiver (http://creativecommons.org/publicdomain/zero/1.0/) applies to the data made available in this article, unless otherwise stated. intensively studied and potential application for the control of Escherichia coli in livestock, aquaculture and food products [9-11].

In this work, phage ST0 against Escherichia coli H8 was isolated from industrial wastewater in China. Its morphology, complete genome sequence and bioinformatics analysis were explored. This could provide a better understanding to the development of a possible alternative medicines and biocontrol agents.

\section{Organism information}

\section{Classification and features}

Escherichia coli H8 (ST100), the host to isolate virulent phages, carrying shiga toxin genes $(s t x 1$, stx2) was obtained from the Chinese Center for Disease Control and Prevention. Phage ST0 was isolated from a sewage treatment plant of wastewater in Beijing. The isolation, propagation and titration of phage was done according to the methods described previously [12]. Phage ST0 generated clear plaques on doublelayer plate (Fig. 1a), indicating that it was a virulent phage. The diameter of plaques was 1-2 $\mathrm{mm}$. The transmission electron microscopy image (Fig. 1b) showed that phage ST0 had an icosahedral head approximately $120 \mathrm{~nm}$ in long diameter and $80 \mathrm{~nm}$ in short diameter. Its long tail was about $120 \mathrm{~nm}$ in length and $20 \mathrm{~nm}$ in diameter. Phylogenetic analysis based on complete genome sequences revealed that phage ST0 was closely related to Enterobacteria phage HX01 (Accession JX536493.1), whereas the score was relatively low (Fig. 2). A summary of the isolation 


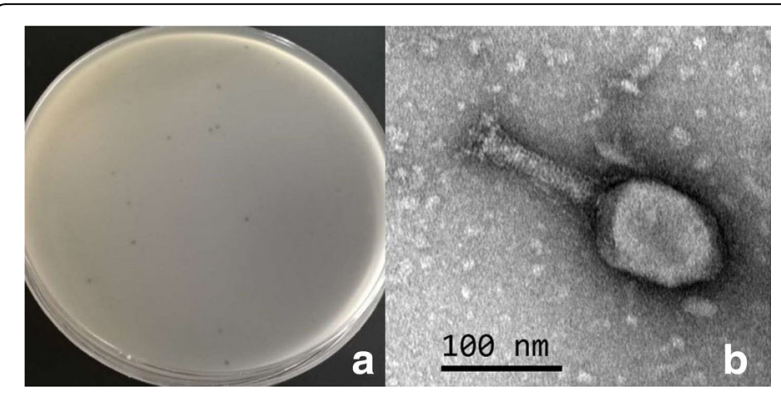

Fig. 1 Characterization of phage ST0 morphology. a The negative colony; b TEM image

and general phylogenetic features of phage ST0 are shown in Table 1.

\section{Genome sequencing information Genome project history}

Phage ST0 infecting Escherichia coli was isolated and sequenced because of its potential for use in phage therapy. The genome sequence and annotation are available in GenBank (MF044457). These data were summarized in Table 2.

\section{Growth conditions and genomic DNA preparation}

Phage ST0 was isolated from a wastewater sample that was filtered through a $0.22-\mu \mathrm{m}$ polycarbonate membrane filter (Millipore, Bedford, MA, USA). The host strain Escherichia coli $\mathrm{H} 8$ was cultured at $37{ }^{\circ} \mathrm{C}$ using $\mathrm{LB}$ medium [13]. Phage DNA was extracted as described by Sambrook and Russell [14]. The phage lysates were concentrated in polyethylene glycol 8000 and bacterial nucleic acids were removed from phage lysates by DNase I (Sigma-Aldrich, Oakville, Canada) and RNaseA (SigmaAldrich). Then the phage particles were amplified and stored in SM buffer (100 mM NaCl, $8 \mathrm{mM} \mathrm{MgSO}$, $50 \mathrm{mM}$ Tris- $\mathrm{HCl}[\mathrm{pH} 7.5])$ at $4{ }^{\circ} \mathrm{C}$.

\section{Genome sequencing and assembly}

DNA was sequenced using the Illumina HiSeq 2500 platform in Beijing Fixgene Tech Co., Ltd. More than 5000 -fold coverage of the phage genome is generated by sequencing the cloned fragments. The paired-end reads were assembled using the abyss v. 1.3.6. Possible tRNAs in the genome were determined using tRNAscan-SE. These data were summarized in Table 3.

\section{Genome annotation}

The potential ORFs were predicted using PHASTER [15]. Putative protein function of ORFs was annotated by BLASTp against NCBI database and HMMER search against the COG database [16] (These data were summarized in Table 4). The map of a circular representation of phage ST0 genome was generated using CGView Server. Neighbor joining tree was drawn by MEGA 5.05 [17].

\section{Genome properties}

The complete genome sequence of phage ST0 had been deposited in GenBank with the accession number MF044457. The complete genome sequence of phage ST0 consisted of 170,496 bp and was circular double-stranded DNA with an average GC content of $37.67 \%$. There were ten tRNAs detected in this genome indicating that phage ST0 could be reliant on its tRNAs after entering into the hosts.

A total of 269 ORFs were predicted in this complete genome, compared with those from the NCBI database (Fig. 3; Additional file 1: Table S1). These ORFs showed more than 94\% identity with 18 different phage strains. Of those, 41 ORFs were predicted in the minus strand and others were in the plus strand. Eighty nine putative ORFs were predicted to have unkown functions.

\section{Insights from the genome sequence}

Phage ST0 possessed replication-related genes encoding DNA polymerase (ORF64), DNA primase/helicase

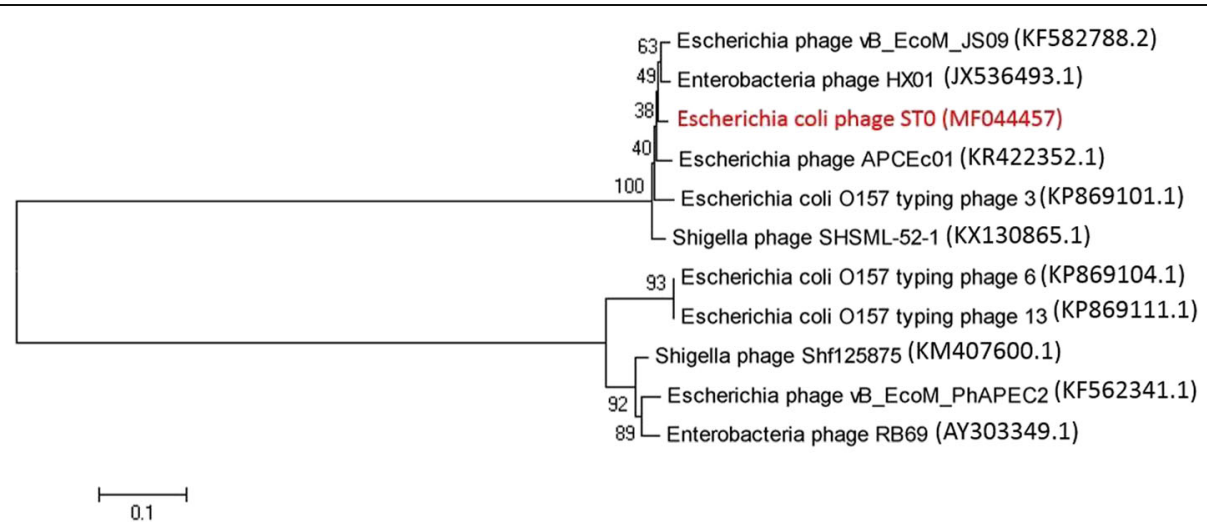

Fig. 2 Neighbor-joining phylogenetic tree based on the complete genome sequence of phage STO 
Table 1 Classification and general features of Genusspecies strain designation ${ }^{\top}$ [19]

\begin{tabular}{|c|c|c|c|}
\hline MIGS ID & Property & Term & Evidence code ${ }^{a}$ \\
\hline & Classification & Domain: Viruses, dsDNA viruses & TAS [21] \\
\hline & & Phylum: unassigned & \\
\hline & & Class: unassigned & \\
\hline & & Order: Caudovirales & TAS [21] \\
\hline & & Family: Siphoviridae & TAS [21] \\
\hline & & Genus: unassigned & \\
\hline & & Species: unassigned & \\
\hline & & (Type) strain: unassigned & \\
\hline & Gram stain & N/A & \\
\hline & Cell shape & N/A & \\
\hline & Motility & N/A & \\
\hline & Sporulation & N/A & \\
\hline & Temperature range & N/A & \\
\hline & Optimum temperature & N/A & \\
\hline & $\mathrm{pH}$ range; Optimum & N/A & \\
\hline & Carbon source & N/A & \\
\hline MIGS-6 & Habitat & Water & IDA \\
\hline MIGS-6.3 & Salinity & N/A & \\
\hline MIGS-22 & Oxygen requirement & N/A & \\
\hline MIGS-15 & Biotic relationship & Intracellular parasite of Escherichia coli H8 & IDA \\
\hline MIGS-14 & Pathogenicity & Lytic phage of Escherichia coli H8 & IDA \\
\hline MIGS-4 & Geographic location & China & IDA \\
\hline MIGS-5 & Sample collection & April, 2017 & IDA \\
\hline MIGS-4.1 & Latitude & $40^{\circ} \mathrm{N}$ & IDA \\
\hline MIGS-4.2 & Longitude & $116^{\circ} \mathrm{E}$ & IDA \\
\hline MIGS-4.4 & Altitude & Unknown & \\
\hline
\end{tabular}

aEvidence codes - IDA inferred from direct assay, TAS traceable author statement (i.e., a direct report exists in the literature). These evidence codes are from the Gene Ontology project [20]

Table 2 Project information

\begin{tabular}{lll}
\hline MIGS ID & Property & Term \\
\hline MIGS 31 & Finishing quality & Complete \\
MIGS-28 & Libraries used & Illumina library \\
MIGS 29 & Sequencing platforms & Illumina HiSeq 2500 \\
MIGS 31.2 & Fold coverage & 5000-folds \\
MIGS 30 & Assemblers & Abyss 1.3.6 \\
MIGS 32 & Gene calling method & PHASTER \\
& Locus Tag & N/A \\
& Genbank ID & MF044457 \\
& GenBank Date of Release & 28-JUN-2017 \\
& GOLD ID & N/A \\
& BIOPROJECT & N/A \\
MIGS 13 & Source Material Identifier & N/A \\
& Project relevance & Isolation and application of phages infecting Escherichia coli
\end{tabular}


Table 3 Genome statistics

\begin{tabular}{lll}
\hline Attribute & Value & \% of Total \\
\hline Genome size (bp) & 170,496 & 100.00 \\
DNA coding (bp) & 157,610 & 92.44 \\
DNA G + C (bp) & 64,218 & 37.67 \\
DNA scaffolds & 0 & 100.00 \\
Total genes & 269 & 100.00 \\
Protein coding genes & 269 & 100.00 \\
RNA genes & 12 & 0.55 \\
Pseudo genes & 0 & 0.00 \\
Genes in internal clusters & 0 & 0.00 \\
Genes with function prediction & 89 & 33.09 \\
Genes assigned to COGs & 121 & 44.98 \\
Genes with Pfam domains & 0 & 0.00 \\
Genes with signal peptides & 0 & 0.00 \\
Genes with transmembrane helices & 0 & 0.00 \\
CRISPR repeats & 0 & 0.00 \\
\hline
\end{tabular}

(ORF76, ORF87, ORF101 and ORF195), DNA ligase (ORF179), topoisomerase (ORF110, ORF121), DNA binding protein (ORF139, ORF142), terminase (ORF211 and ORF212) and other related proteins (ORF7, ORF18, ORF33, ORF34, ORF60-62, ORF89, ORF138, ORF146-147, ORF149-151, ORF159, ORF166, ORF231 and ORF259). Terminase was observed in the phage ST0 genome, and plays the essential role in the double-stranded DNA packaging process. Terminase generally composed of two subunits identifies the pre-capsid protein and the specific packaging sites, providing energy to packaging process through hydrolysis of ATP $[17,18]$. This showed that phage ST0 possibly depended on its own terminase to obtain these kinds of function, while many phages lacked this enzyme.

Phage ST0 may be dependent on its own gene transcription and translation, because it possessed RNArelated enzymes such as tRNA synthetase modifier (ORF2), putative thioredoxin (ORF28), RNA polymerase sigma factor (ORF49), RNA ligase (ORF152 and ORF200) and other related proteins (ORF59, ORF63,

Table 4 Number of genes associated with general COG functional categories

\begin{tabular}{|c|c|c|c|}
\hline Code & Value & \%age & Description \\
\hline J & 2 & 0.74 & Translation, ribosomal structure and biogenesis \\
\hline A & 0 & 0.00 & RNA processing and modification \\
\hline K & 7 & 2.60 & Transcription \\
\hline L & 15 & 5.58 & Replication, recombination and repair \\
\hline B & 0 & 0.00 & Chromatin structure and dynamics \\
\hline $\mathrm{D}$ & 2 & 0.74 & Cell cycle control, Cell division, chromosome partitioning \\
\hline V & 2 & 0.74 & Defense mechanisms \\
\hline $\mathrm{T}$ & 3 & 1.12 & Signal transduction mechanisms \\
\hline M & 5 & 1.86 & Cell wall/membrane biogenesis \\
\hline N & 0 & 0.00 & Cell motility \\
\hline$U$ & 0 & 0.00 & Intracellular trafficking and secretion \\
\hline O & 6 & 2.23 & Posttranslational modification, protein turnover, chaperones \\
\hline C & 2 & 0.74 & Energy production and conversion \\
\hline G & 4 & 1.49 & Carbohydrate transport and metabolism \\
\hline E & 6 & 2.23 & Amino acid transport and metabolism \\
\hline $\mathrm{F}$ & 9 & 3.35 & Nucleotide transport and metabolism \\
\hline $\mathrm{H}$ & 2 & 0.74 & Coenzyme transport and metabolism \\
\hline । & 0 & 0.00 & Lipid transport and metabolism \\
\hline P & 2 & 0.74 & Inorganic ion transport and metabolism \\
\hline Q & 0 & 0.00 & Secondary metabolites biosynthesis, transport and catabolism \\
\hline $\mathrm{R}$ & 0 & 0.00 & General function prediction only \\
\hline S & 54 & 20.07 & Function unknown \\
\hline- & 148 & 55.02 & Not in COGs \\
\hline
\end{tabular}




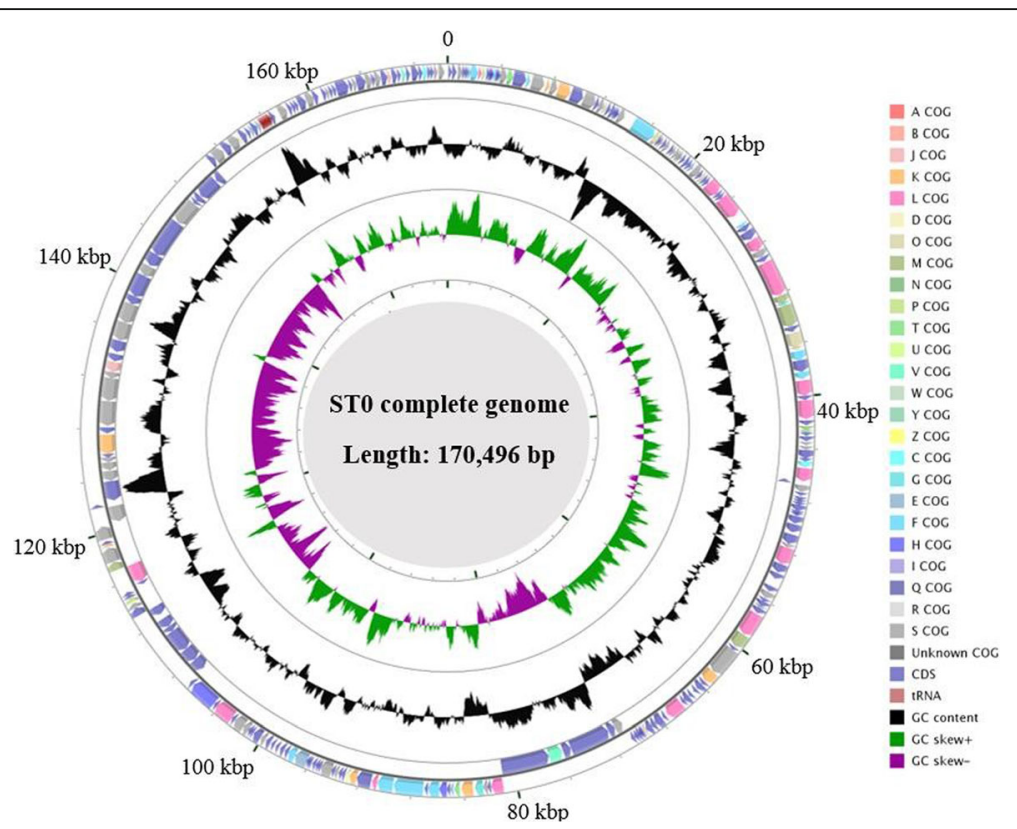

Fig. 3 CGView Server map of phage STO complete genome

ORF123, ORF140, ORF165, ORF181) to regulate gene expression.

Forty one genes that were related to the structure of phage ST0 were identified in its genome, including phage virion protein and tail tube. The ORFs related to structure were mainly concentrated between $106,926 \mathrm{bp}$ and $153,860 \mathrm{bp}$, which facilitated the rapid assembly of phages and also reflected the lowest energy principle in nature.

The presence of lysozyme (ORF257) and holing (ORF132) indicated that phage ST0 was a lytic phage. Moreover, other several active factors played a quite important role in host cell lysis and inhibition of host cell growth, such as exonuclease (ORF102), inhibitor of host transcription (ORF153), nudix hydrolase (ORF256) and rIIA protein (ORF113, ORF114 and ORF169).

\section{Conclusions}

The morphology, complete genome sequence and bioinformatics analysis showed phage ST0 was a novel virulent phage infecting and lysing Escherichia coli H8, which may provide a better understanding to the development of a possible alternative medicines and biocontrol agents.

\section{Additional file}

Additional file 1: Table S1. Predicted protein function of phage STO (DOCX $53 \mathrm{~kb}$ )

\section{Abbreviations}

TEM: Transmission electron microscopy

\section{Acknowledgements}

We wish to thank Dr. Yanwen Xiong of Collaborative Innovation Center for Diagnosis and Treatment of Infectious Diseases, State Key Laboratory of Infectious Disease Prevention and Control, National Institute for Communicable Disease Control and Prevention, Chinese Center for Disease Control and Prevention for providing Escherichia coli H8 (ST100). We also wish to thank Miss Jingnan Liang of the Institute of Microbiology, Chinese Academy of Sciences for her assistance in TEM sample preparation.

\section{Funding}

This study was funded by grant National Natural Science Foundation of China (No. 50978250 and No. 51378485), and the Resources and Environment Bureau of Chinese Academy of Sciences (No.Y225018EA2).

\section{Authors' contributions}

$\mathrm{XL}$ designed, guided the experiment and wrote this manuscript. HL was mainly responsible for the implementation of the experiment and writing this manuscript. JL provided the wastewater sample for isolating phage and assisted the experiment. All authors read and approved the final manuscript.

\section{Competing interests}

The authors declare that they have no competing interests.

\section{Publisher's Note}

Springer Nature remains neutral with regard to jurisdictional claims in published maps and institutional affiliations.

Received: 19 July 2017 Accepted: 6 December 2017 Published online: 19 December 2017

\section{References}

1. Daghrir R, Drogui P. Tetracycline antibiotics in the environment: a review. Environ Chem Lett. 2013;11:209-27.

2. Gandolfi I, Franzetti A, Bertolini V, Gaspari E, Bestetti G. Antibiotic resistance in bacteria associated with coarse atmospheric particulate matter in an urban area antibiotic resistance in atmosphere. J Appl Microbiol. 2011; 110(6):1612-20

3. Tasho RP, Cho JY. Veterinary antibiotics in animal waste, its distribution in soil and uptake by plants: a review. Sci Total Environ. 2016;563-564:366-76. 
4. Ding C, He J. Effect of antibiotics in the environment on microbia populations. Appl Microbiol Biotechnol. 2010;87:925-41.

5. Jechalke S, Heuer H, Siemens J, Amelung W, Smalla K. Fate and effects of veterinary antibiotics in soil. Trends Microbiol. 2014;22:536-45.

6. Coutinho FH, Silveira CB, Pinto LH, Salloto GRB, Cardoso AM, Martins $\mathrm{OB}$, Vieira RP, Clementino MM. Antibiotic resistance is widespread in urban aquatic environments of Rio de Janeiro, Brazil. Microbiol Ecol. 2014;68:441-52.

7. Loc-Carrilloa C, Abedon ST. Pros and cons of phage therapy. Bacteriophage. 2011;1(2):111-4.

8. Kutter E, Vos DD, Gvasalia G, Alavidze Z, Gogokhia L, Kuhl S, Abedon ST. Phage therapy in clinical practice: treatment of human infections. Curr Pharm Biotechnol. 2010;11:69-86.

9. Mateus L, Costa L, Silva YJ, Pereira C, Cunha A, Almeida A. Efficiency of phage cocktails in the inactivation of Vibrio in aquaculture. Aquaculture. 2014;424-425:167-73.

10. Raul R, Rebecca AO, Ben MM, Wieland S, Callaway TR, Kutter E, Brabban AD. Naturally resident and exogenously applied T4-like and T5-like bacteriophages can reduce E.coli 0157:H7 levels in sheep guts. Bacteriophage. 2011;1(1):15-24.

11. Hudson JA, Billington C, Cornelius AJ, Wilson T, On SLW, Premaratne A, King NJ. Use of a bacteriophage to inactivate E.coli O157:H7 on beef. Food Microbiol. 2013;36:14-21

12. Adams MH. Bacteriophage. London, New York: Interscience Publishers, Inc; 1959.

13. Bertani G. Studies on lysogenesis. I. The mode of phage liberation by lysogenic Escherichia coli. J Bacteriol. 1951;62(3):293-300.

14. Sambrook J, Russell D. Molecular cloning: a laboratory manual. 3rd ed. New York: Cold Spring Harbor Laboratory, Cold Spring Harbor; 2001. p. 543-54.

15. Arndt D, Grant JR, Marcu A, Sajed T, Pon A, Liang Y, Wishart DS. PHASTER: a better, faster version of the PHAST phage search tool. Nucleic Acids Res. 2016. doi:10.1093/nar/gkw387.

16. Bryan MJ, Burroughs NJ, Spence EM, Clokie MRJ, Mann NH, Bryan SJ. Evidence for the intense exchange of MazG in marine cyanophages by horizontal gene transfer. PLoS One. 2008;3:e2048.

17. Tamura K, Peterson D, Peterson N, Stecher G, Nei M, Kumar S. MEGA5: molecular evolutionary genetics analysis using maximum likelihood, evolutionary distance, and maximum parsimony methods. Mol Biol Evol. 2011;28(10):2731-9.

18. Field D, Garrity GM, Gray T, Morrison N, Selengut J, Sterk P, et al. The minimum information about a genome sequence (MIGS) specification. Nat Biotechnol. 2008;26:541-7.

19. Ashburner M, Ball CA, Blake JA, Botstein D, Butler H, Cherry JM, et al. Gene ontology: tool for the unification of biology. The gene ontology consortium. Nat Genet. 2000;25:25-9.

20. Fauquet CM, Mayo MA, Maniloff J, et al. Virus taxonomy: VIIIth report of the international committee on taxonomy of viruses. San Diego: Elsevier Academic Press; 2005.

21. Niehol S, Beaty B, Elliott R. Bunyaviridae//Fauquet CM, Mayo MA, Maniloff J, et al. (eds). Virus Taxonomy. VIIlth Report of the International Committee on Taxonomy of Viruses. Amsterdam: Elsevier Academic Press; 2005.

\section{Submit your next manuscript to BioMed Central and we will help you at every step:}

- We accept pre-submission inquiries

- Our selector tool helps you to find the most relevant journal

- We provide round the clock customer support

- Convenient online submission

- Thorough peer review

- Inclusion in PubMed and all major indexing services

- Maximum visibility for your research

Submit your manuscript at www.biomedcentral.com/submit
Biomed Central 